Environmental Law Review

In the Matter of the South China Sea Arbitration: Republic of Philippines v People's Republic of China, Arbitral Tribunal Constituted under Annex VII to the I 982 United Nations Law of the Sea Convention, Case No. 2013-19, Award of I2 July 2016

(C) The Author(s) 2016 Reprints and permission: sagepub.co.uk/journalsPermissions.nav I0.1 I77/|461452916680866 elj.sagepub.com (SAGE

\title{
Duncan French
}

Head of Lincoln Law School and Professor of International Law, University of Lincoln, Lincoln, UK

\section{Keywords}

Endangered species, exclusive economic zone, marine conservation, protection of marine environment, sovereignty, territorial sea, United Nations Convention on the Law of the Sea

The Award in the Matter of the South China Sea issued by an arbitral tribunal in July 2016 is a major contribution to the jurisprudence on the law of the sea, the rules of marine environmental protection and various other aspects of general international law and dispute settlement. It is, of course, beyond this case note to answer whether the Award will ultimately contribute to the peaceful resolution of one of the most intractable and contentious international situations. Nevertheless, as an Award given under a treaty - the 1982 United Nations Convention on the Law of the Sea (UNCLOS) - that is binding on both States as parties thereto, '[i]t goes without saying that both Parties are obliged to resolve their dispute peacefully and to comply with the Convention and this Award in good faith'. ${ }^{1}$

Within the scope of a case note it is not possible to detail the geo-politics of the dispute or to reflect on its future significance. In fact, as it runs to over 475 pages, it is difficult to do little more than outline some of the legal issues arising from the Award. Nevertheless, despite its length and complexity, the Award represents at its heart a classical reassertion of the necessary balancing of rights and obligations that UNCLOS has always sought to achieve. As the preamble to the Convention very famously had cause to note: 'the desirability of establishing through this Convention, with due regard for the sovereignty of all States, a legal order for the seas'.

The case note is divided into three parts; Part 1 will provide an overview of the dispute and a history of the proceedings and Part 2 will provide a summary of some of the key findings - and underlying reasoning to many of the most contentious issues on maritime entitlement. Part 3 will then focus on those aspects of the 
Award more specifically related to environmental protection and the conservation of natural resources. The case note will conclude by suggesting that notwithstanding the low probability of China's formal compliance with the Award, the reasoning in this Award will be influential both as a matter of general international law but it will also likely reframe the South China Sea dispute whether its leading protagonist wishes it to or not.

\section{Part I: History of the Dispute}

The present legal proceedings began with the submission by the Philippines of a unilateral application under UNCLOS rules on dispute resolution on 22 January 2013. One of the singular strengths of UNCLOS is the inclusion of a compulsory dispute settlement process - admittedly with various exceptions and caveats which allows one side of a dispute to initiate proceedings before a range of dispute settlement institutions. As with many of the disputes where there is no prior consensus on dispute settlement, it is heard before an arbitral tribunal under Annex VII UNCLOS. China rejected the Philippines right to bring the arbitration, and has not participated in the proceedings at any point. Nevertheless, as Article 9 of Annex VII UNCLOS expressly states: '[a]bsence of a party or failure of a party to defend its case shall not constitute a bar to the proceedings'. The arbitral tribunal has thus had to take special measures to ensure that China's interests are fully respected within the procedure and its likely arguments considered in its deliberations. Whilst not participating in the proceedings, China has issued various Notes Verbales and made other statements which have given the arbitration tribunal some understanding of the Chinese position.

Of key importance has been the scope of the legal dispute. The international situation in the South China Sea is a complex interplay of land and maritime disputes, involving not only the Philippines and China but also many of the other regional States, including Malaysia, Vietnam and Brunei, as well as other maritime powers, including, notably, the United States. Many of the disputes revolve around questions of sovereignty of land but, as a treaty on maritime affairs, UNCLOS does not address territorial sovereignty, nor can its dispute resolution procedures resolve maritime disputes that implicitly require the underlying territorial sovereignty also to be adjudged. As a general principle of international law, 'the land dominates the sea' and thus a State's sovereignty over maritime areas flows from its sovereignty of its land territory. To avoid this insurmountable jurisdictional issue, the Philippines' claims were narrowly constructed to avoid questions of territorial sovereignty, or in any way requiring the Tribunal to delimit maritime boundaries (which would invariably require agreement or a judgment on the sovereignty over particular territory). Rather, the Philippines' claims revolved around three broad areas:

1. that all maritime entitlements in the South China Sea are to be determined in accordance with the rules of UNCLOS, and that in particular the Chinese claim to expansive historic rights under its 'Nine-Dash line' marked out on Chinese maps is contrary to UNCLOS;

2. that various maritime features claimed by both sides are either low-tide elevations (which exist above the surface at low-tide but are submerged at high-tide), and which according to international law do not generate their own maritime zones, or that they are rocks (in contrast to being classed as islands) and thus do not generate substantial maritime zones beyond 12 nautical miles; and

3. various disputes concerning Chinese activities in the South China Sea, such as the construction of artificial islands and land reclamation (which, in many cases, was allegedly causing severe environmental harm), infringement of the Philippines' sovereign rights in its exclusive economic zone, allowing its fishermen to harvest endangered species and to use harmful fishing methods, and incidences of near-miss collisions.

The Philippines also sought for the Tribunal to find that China had aggravated the dispute during the course of the arbitration through various artificial construction and land reclamation activities, as well as 
restricting movement of the Philippines military in a particular area. ${ }^{2}$ In all, the Philippines brought forward 15 claims ('Submissions') against China.

In an initial Award on Jurisdiction and Admissibility issued on 29 October 2015, the Tribunal found that China's absence was not a bar to the proceedings, that the Philippines had not abused the process by initiating the arbitration (as China had alleged), and that the Philippines had not agreed to another dispute resolution procedure for the South China Sea dispute that would exclude arbitration under UNCLOS. As regards the claims themselves, the Tribunal found that it had clear jurisdiction over seven of the claims, that it might have jurisdiction over seven of the other claims subject to what was decided on the merits and, as regards one claim, the Tribunal sought further clarification as to its scope. Significantly, the Tribunal noted that it 'does not see that any of the Philippines' Submissions require an implicit determination of sovereignty... The Tribunal... intends to ensure that its decision neither advances nor detracts from either Party's claims to land sovereignty in the South China Sea'. ${ }^{3}$

\section{Part 2: Award on Merits: General Issues}

As previously noted, the Tribunal, in reaching its findings in the Award of 12 July 2016, had to do so without the participation of Chinese counsel and what undoubtedly would have been the submission of detailed Chinese arguments, both on the law and on many technical aspects. In part to compensate for this, the Tribunal appointed various experts to advise on particular issues, notably navigational safety and coral reefs. Moreover, though it did not participate, China did take the opportunity to make numerous statements on the arbitration process as well as to write to the individual arbitrators on various matters. Excerpts of each of these are all included in the Tribunal's Award. The Tribunal also made significant use of material in the public domain, seeking views from both parties on such sources, which China neither directly commented on, nor replied to. As a matter of process, the Tribunal was thus seeking to ensure procedural fairness, as well as recognising that, as a matter of law, it was not permitted simply to accept the Philippines' arguments but must satisfy itself 'not only that it has jurisdiction over the dispute but also that the claim is well founded in fact and law'.

In what will be perhaps the most contentious finding for China, the Tribunal ruled against the legality of the 'Nine-Dash line', the Chinese claim to historic rights in the South China Sea. The finding of the Tribunal is extensively reasoned but at its simplest it is premised on two key findings. First, that ' $[\mathrm{t}]$ he Convention thus provides - and defines limits within - a comprehensive system of maritime zones that is capable of encompassing any area of sea or seabed'. ${ }^{5}$ Secondly, that 'upon China's accession to the Convention ... any historic rights that China may have had to the living and non-living resources within the 'nine-dash line' were superseded ... by the limits of the maritime zones provided for by the Convention'. ${ }^{6}$ Indeed, the Tribunal goes on to note that such a finding 'should not be considered exceptional or unexpected'?

The Tribunal is very careful, however, to place this hugely symbolic loss to China within the context of what it has gained by joining UNCLOS. As a useful summary of the balancing of rights and responsibilities which all States parties are required to respect, it is worth quoting in full:

2. As regards those claims relating to disputes concerning military activities, the Tribunal ruled that it did not possess jurisdiction by virtue of the exception declared by China as permitted under Art. 298(1)(b) UNCLOS.

3. Award on Jurisdiction and Admissibility of 29 October 2015, para. 153.

4. Article 9, Annex VII UNCLOS. Emphasis added.

5. Award of 12 July 2016, para. 231.

6. Ibid, para. 262.

7. Ibid. 
China's ratification of the Convention ... did not extinguish historic rights in the waters of the South China Sea. Rather, China relinquished the freedoms of the high seas that it had previously utilised with respect to the living and non-living resources of certain sea areas which the international community had collectively determined to place within the ambit of the exclusive economic zone of other States. At the same time, China gained a greater degree of control over the maritime zones adjacent to and projecting from its coasts and islands. China's freedom to navigate the South China Sea remains unaffected. ${ }^{8}$

In addition to ruling on the Nine-Dash line, the Tribunal was called on to characterise several maritime features, the effect of such characterisation being then to determine the extent of its maritime entitlement. In short, low-tide elevations - a maritime feature not visible at high tide - creates no entitlement to a maritime zone, though it may be used to determine the baseline from which such zones are measured. However, rocks - a maritime feature visible at high tide - do create an entitlement to a territorial sea of 12 nautical miles, though only an island (Article 121(3) UNCLOS) generates an entitlement to a 200 nautical miles continent shelf and an exclusive economic zone. Thus, this arbitration required the Tribunal to differentiate between different maritime features, especially between a rock and an island, the latter needing to be able to show that it has the capacity to 'sustain human habitation or economic life of [its] own'. These are distinctly legal questions, but equally they are open to factual interpretation and the existence and availability of appropriate evidence, including photographic and satellite imagery.

Before briefly outlining the Tribunal's findings, three comments are worth mentioning. First, human modification of low-tide elevations - through reclamation or artificial construction - will not change the original nature of the feature. As the Tribunal notes, '[a]s a matter of law, human modification cannot change the seabed into a low-tide elevation or a low-tide elevation into an island'. ${ }^{9}$ Rather, 'the Convention requires that the status of a feature be ascertained on the basis of its earlier, natural condition, prior to the onset of significant human modification'. ${ }^{10}$

Secondly, to determine whether something is a low-tide elevation or a high-tide rock required the Tribunal to determine 'high tide'; the vertical datum. As the Tribunal notes, high tide is subject to various possible interpretations, including 'mean high water', 'mean higher high water' and 'mean high water springs'. It is further complicated by the fact that the South China Sea is a semi-enclosed sea, which affects regional tidal patterns. The essentially scientific issue of determining the tidal range thus posed an important issue for the Tribunal as the legal implications were significant. The Tribunal relied heavily on historical observations by, inter alia, the British Royal Navy and the Japanese Navy, as well as information contained in modern Chinese charts. The Tribunal was less convinced by the evidence submitted by the Philippines via remote sensing through satellite imagery. Recognising its probative value in certain circumstances, the Tribunal queries how far conclusions can be drawn from such images, especially as 'the time of image capture will generally not align with either high or low tide'. ${ }^{11}$

A third issue - of direct relevance here, but undoubtedly of general importance in the longer-term interpretation of the Convention - is when does a rock meet the criteria to become an island? As noted above, Article 121(3) sets out conditions of human habitation or economic life; indeed the Tribunal spends five paragraphs discussing the 'or' between these terms, concluding in fact that, in most instances, 'humans will rarely inhabit areas where no economic activity or livelihood is possible'. ${ }^{12}$ The Tribunal looks deeply

8. Ibid, para. 271.

9. Ibid, para. 305 .

10. Ibid, para. 306 .

11. Ibid, para. 323 .

12. Ibid, para. 497. The Tribunal does acknowledge, however, that there may be instances 'where multiple islands are used in concert to sustain a traditional way of life'. 
into the object and purpose of the Convention, the literal meaning of the words and the travaux préparatoires of the negotiations to ascertain its true meaning. It makes a number of important statements. First, similarly to the assessment of low-tide elevations, its status is to be determined 'on the basis of its natural capacity, without external additions or modifications'. ${ }^{13}$ Secondly, the key factor to determine whether there is human habitation is 'the non-transient character of the inhabitation', namely 'the inhabitation of the feature by a stable community of people for whom the feature constitutes a home and on which they can remain'. ${ }^{14}$ Thirdly, for a feature to have an 'economic life of its own' it must be capable of sustaining the economic life of the inhabitants; the Tribunal views this as not being met either when '[e]conomic activity... is entirely dependent on external resources' (including placing reliance on the maritime resources of its surrounding waters or seabed) or when it is 'devoted to using a feature as an object for extractive activities without the involvement of a local population'. ${ }^{15}$

As interesting as these findings are, it is their application to the facts of this dispute, which is likely to be particularly contentious. The Tribunal examines in great detail the application of the criteria to the rocks and elevations in the Spratly Islands that are above water at high-tide. Examining the presence of potable water, and studies on vegetation and agricultural productivity, as well as historical accounts of their use by fishermen, the Tribunal concludes that none of the rocks meet the criteria to be an island laid out in the Convention. The dismissal of the presence of sufficiently sustainable groups of fishermen is likely to prove especially controversial with China, especially as the Tribunal itself recognises that some of these men were present 'for comparatively long periods of time'. ${ }^{16}$ Nevertheless, this is as much about policy as it is the historical record, with the Tribunal noting that it was not the purpose of the Convention to generate expansive maritime entitlements for features 'whose historical contribution to human settlement is as slight as that'. ${ }^{17}$ Is this judicial interpretation of open-textured provisions or extra-judicial decision-making? Either way, this Award will provide the new international standard for what is an island for the purposes of the law of the sea.

On the basis of these and other findings, the Tribunal was able to identify those features which were lowtide elevations and those which were rocks and ruled against any being islands. For the most part, these rulings were to the benefit of the Philippines' claims. More importantly, for the Philippines, by not finding any feature to be an island, the result was that two of the most contested features - Mischief Reef and Second Thomas Shoal (which the Tribunal had found to be low-tide elevations) - are thus located with the established exclusive economic zone of the Philippines, and as it is not within 200 nautical miles of any feature to which China could possibly claim sovereignty, these key features remain part of the maritime entitlement of the Philippines. It is worthwhile pausing here to reflect what the Tribunal has done. It has not ruled on sovereignty but, in effect, it has. By finding that something is a low-tide elevation (the first-order question), incapable of being possessed by means of territoriality, the Tribunal has in essence ruled out the question of sovereignty (a second-order question). As a matter of formal law, it ensures a coherent and internally logical Award, but one might wonder how far this legal deduction will be persuasive within internal Chinese political deliberations or in international negotiations?

\section{Part 3: Award on Merits: Specific Findings on Marine Environmental Harm}

If much of the popular attention surrounding the Award is on the dismissal of the Nine-Dash line, this would fail to capture the Philippines' multiple claims around environmental harm, the utilisation of natural

\footnotetext{
13. Ibid, para. 541.

14. Ibid, para. 542 .

15. Ibid, para. 543 .

16. Ibid, para. 601 .

17. Ibid, para. 621 .
} 
resources, and the failure of China to regulate appropriately its fishing fleet and related complaints. In fact, the complaints upheld are sufficiently numerous that it is useful to provide them in summary form:

1. China violated the Philippines' sovereign rights over non-living resources in its continental shelf by interfering in lawful surveying activity by the Philippines.

2. China violated the Philippines' sovereign rights over living resources in its exclusive economic zone by issuing a moratorium on fishing in the South China Sea, without exception to either Philippines' maritime zones or whether it applied to domestic or foreign fishing fleet.

3. China violated Philippines' sovereign rights in the exclusive economic zone by failing to exercise due diligence in preventing fishing by Chinese-registered vessels.

4. Notwithstanding the unresolved issue of sovereignty over Scarborough Shoal, China acted unlawfully by preventing traditional fishing by Filipino fishermen. ${ }^{18}$

5. China violated UNCLOS provisions on protecting the marine environment by failing to act with due diligence in preventing Chinese-registered vessels from undertaking harmful fishing practices and harvesting endangered species, in particular the harvesting of sea turtles, giant clams and the damage done to coral reefs.

6. China violated various UNCLOS provisions on protecting the marine environment by undertaking land reclamation activities and constructing artificial islands causing severe harm to coral reefs.

7. China aggravated the dispute during the course of the arbitration by continuing to undertake construction works on various reefs, inflicting severe and irreparable harm on the natural coral, as well as destroying evidence of the natural condition of such reefs.

These proven claims were not the only submissions made. For instance, it was claimed that China permitted its fishermen to use explosives and cyanide as fishing techniques. The Tribunal considered the submissions but found it had insufficient evidence on which to rule. ${ }^{19}$ Nevertheless, it is clear from the extent of the rulings against China that the South China Sea is facing substantial, sustained and, in some cases, severe environmental damage. As the Award states, in relation to the artificial construction activities, ' $[\mathrm{t}]$ he conclusions of the Tribunal-appointed independent experts are unequivocal with respect to the more recent construction activities, which they say have "impacted reefs on a scale unprecedented in the region", 20

It is not possible within the scope of this case note to provide a detailed analysis of the application of the relevant marine environmental provisions of UNCLOS. Nevertheless, a few key points can be made. First, the recognition at numerous points that China is not only responsible for its own activities which violate UNCLOS, but also for those of its nationals where harm also occurs is significant. This latter responsibility is, however, not an absolute one but is an obligation of conduct, framed in terms of due diligence. This is discussed at several points in the Award, notably in relation to its failure to prevent Chinese fishing in the Philippine exclusive economic zone (item (c) above) and failing to prevent harmful fishing practices and damage to sensitive ecosystems (item (e) above).

As regards the former, the Tribunal admits that exercising due diligence over fishermen acting unlawfully cannot always be easily determined: '[o]ften unlawful fishing will be carried out covertly, far from any

18. The discussion of traditional, or artisanal, fishing is particularly interesting (see paras 794-804). The Tribunal is careful to note how traditional fishing is preserved (and thus can be distinguished from a State's historic rights, which have been extinguished); ' $[\mathrm{t}]$ hese are not the historic rights of States ... but private rights [unconnected to] "the western legal fiction ... whereby all legal rights, even those in reality held by individuals, were deemed to be those of the State" " (para. 798, quoting Eritrea v Yemen, Award of 17 December 1999, para. 101).

19. Ibid, para. 975 .

20. Ibid, para. 978. 
official presence, and it will be far from obvious what the flag State could realistically have done to prevent it'. ${ }^{21}$ However, in this instance, the Tribunal not only finds an absence of due diligence but also something close to collusion between fishermen and the State; the evidence 'support[s] an inference that China's fishing vessels are not simply escorted and protected, but organised and coordinated by the Government'. ${ }^{22}$

A secondary aspect of due diligence is evidenced later in the Award where the Tribunal is discussing the obligations expected of States to prevent ships flying their flag from breaching the environmental provisions, in this case Articles 192 (the general obligation: 'States have the obligation to protect and preserve the marine environment') and 194 (measures to prevent, reduce and control pollution). As the Tribunal notes, relying on jurisprudence from the International Tribunal for the Law of the Sea, ${ }^{23}$ the Seabed Disputes Chamber $^{24}$ and the International Court of Justice, ${ }^{25}$ such obligations require due diligence 'in the sense of a flag State not only adopting appropriate rules and measures, but also 'a certain level of vigilance in their enforcement and the exercise of administrative control'. ${ }^{26}$ On the facts before it, the Tribunal notes that while measures and rules may have been adopted to prevent harmful fishing practices - namely a 1989 Chinese wildlife law which prohibits, inter alia, the catching of sea turtles and giant clams - '[t]here is no evidence... that would indicate that China has taken any steps to enforce those rules'. ${ }^{27}$ This is to be contrasted with the position that the Tribunal takes on the allegation of use of cyanide and explosives, where it indicates that there is no evidence that China has failed to enforce its own rules in this regard. ${ }^{28}$

As regards the construction of artificial islands over low-tide elevations and reefs - activities undertaken by China itself - the obligation is not one of due diligence, but rather can be directly imputed to it. Based on the evidence provided and the report of experts, the Tribunal makes some of its strongest pronouncements in relation to this submission. Finding that the artificial island-building has 'caused devastating and longlasting damage to the marine environment', the Tribunal finds a violation of Article 192 (the general obligation), that dredging has caused marine pollution contrary to Article 194(1), and that it has failed to protect rare or fragile ecosystems contrary to Article 194(5). In addition, the Tribunal finds that China has failed to cooperate with neighbouring States under Article 197 and, as the South China Sea is a semienclosed sea, also violated the obligations under Article 123 of UNCLOS.

Importantly, the Tribunal also found that China had failed to follow the appropriate procedure necessary to undertake an impact assessment under Article 206. ${ }^{29}$ This obligation requires a State to undertake and communicate such an assessment where they have 'reasonable grounds for believing that planned activities under their jurisdiction or control may cause significant and harmful changes to the marine environment'. Unable to finally determine whether such an impact assessment had, in fact, been undertaken, the Tribunal noted that a key feature of Article 206 was nevertheless its requirement that a State communicate such an assessment, which it was apparent to the Tribunal had not occurred either bilaterally to the Philippines or to competent multilateral organisations. Building on the recent judgment of the International Court in Construction of a Road (Nicaragua v Costa Rica), ${ }^{30}$ the Tribunal noted that it was necessary for a State

21. Ibid, para. 754 .

22. Ibid, para. 755 .

23. Request for an Advisory Opinion Submitted by the Sub-Regional Fisheries Commission (SRFC), Advisory Opinion of 2 April 2015.

24. Responsibilities and Obligations of States Sponsoring Persons and Entities with Respect to Activities in the Area, Advisory Opinion of 1 February 2011.

25. Pulp Mills on the River Uruguay (Argentina v Uruguay), ICJ Reports (2010) 4.

26. Award of 12 July 2016, para. 944, quoting Pulp Mills on the River Uruguay, para. 197.

27. Ibid, para. 964.

28. Ibid, para. 974.

29. Ibid, para. 989.

30. See ICJ Reports (2015) para. 154. 
to do more than merely assert that such an assessment existed; rather it had to prove its existence. Moreover, in something akin to judicial renvoi, the Tribunal relies on China's own environmental impact assessment law to identify how China had failed to comply with its own domestic requirements. ${ }^{31}$

Finally, it should be noted that the Tribunal found against China (item (7) above) by noting how China had undertaken various environmentally damaging activities during the period that the arbitration had been ongoing, thus aggravating the dispute still further. In some cases irreparable damage had now occurred to several of the maritime features. Indeed, at Mischief Reef - perhaps aptly named - 'China has effectively created a fait accompli ... by constructing a large artificial island ... In practical terms, the implementation of the Tribunal's decision will be significantly more difficult for the Parties, and Mischief Reef cannot be returned to its original state'. ${ }^{32}$

Notwithstanding evidence of such blatant aggravation, the Tribunal reverted to a more traditional stance when faced by a request by the Philippines to adopt a prospective declaration as to China's future conduct. The Tribunal refuses to issue such a declaration believing that the Award itself provides clarity as to each State's respective rights and responsibilities. In what is perhaps an inevitable, but undue, deference to the belief in the authority of international law, the Tribunal suggests that bad faith is not to be presumed and that as ' $[n]$ either Party contests' that they are not bound by the Convention 'including its provisions regards the resolution of disputes ${ }^{33}$ a more proactive declaration is unnecessary. The evidence presented previously as to ongoing aggravation of the dispute might have suggested differently.

\section{Conclusion}

The Tribunal's Award is significant in a number of respects, which have been outlined above. Nevertheless, this is a complex and rich Award deserving of further scrutiny. At best, it is a classical reassertion of the constitutional status of UNCLOS as governing each States Parties' rights and responsibilities under the international law of the sea. As noted above, the Award is particularly strong on holding States to account for environmental damage, in a way that few law of the sea cases have yet done. On this basis, one hopes that it will set a benchmark for other tribunals to follow. However, there is weakness here. In terms of political reality, China is likely to pay scant regard to the Award, and has already dismissed it. ${ }^{34}$ Nevertheless, even without formal compliance, there is no doubt that it will change the tone of the wider debate. Such Awards, once made, cannot be undone, and it will create the framework for future debates and dialogues, even if some of its rulings are politically difficult or - in light of island-building - impossible now to comply with.

Finally, one further thought. Unbeknownst to the Tribunal, this Award is likely to have an effect incidentally and potentially negatively - on a very different environmental subject, namely climate change and sea-level rise. The way in which the Tribunal reasoned against land reclamation and artificial island building, determining the status of a maritime feature exclusively on the basis of its natural state, or that rocks cannot be improved externally to convert them into islands - all rational from the perspective of Statebuilding in the South China Sea - may need to be re-addressed in the future in the very different context of climate change. To the extent that UNCLOS provides a legal framework for one of the most intractable political disputes, this surely gives some hope that it might also provide a basis to answer other challenges erga omnes facing the wider international community.

31. Award of 12 July 2016, para. 990.

32. Ibid, para. 1177.

33. Ibid, para. 1201 .

34. Beijing rejects tribunal's ruling in South China Sea case'. Available at: www.theguardian.com/world/2016/jul/12/philippineswins-south-china-sea-case-against-china (last accessed 12 July 2016). 


\section{Declaration of Conflicting Interests}

The author(s) declared no potential conflicts of interest with respect to the research, authorship, and/or publication of this article.

\section{Funding}

The author(s) received no financial support for the research, authorship, and/or publication of this article. 